E-

\title{
K PROBLEMATIKE VECNEJ A CENOVEJ REGULÁCIE POŠTOVÝCH SLUŽIEB
}

\author{
Lucia Madleňáková*
}

\section{Úvod}

Vzhl'adom k snahe EÚ o maximálne uplatnenie konkurenčných síl na trhu poštových služieb je potrebné redukovat' rozsah poštových monopolov až do ich úplného zrušenia. Do daného okamihu je však potrebné zabezpečit' efektívnu reguláciu poštového sektora vhodnými opatreniami regulačných autorít. Zvláštnu pozornost' je potrebné venovat' vecnej a cenovej regulácií poštových služieb, ale i ochrane spotrebitel'a, ktorý by mohol byt' ohrozený vysokými cenami monopolne postavených služieb či nízkou úrovňou kvality vyplývajúcej z nedostatku konkurencie na poštovom trhu.

\section{Vymedzenie poštového sektora}

Vzhl'adom k rozdielnosti národných legislatív jednotlivých členských štátov a vzhl'adom k existujúcim rôznorodým názorom rôznych subjektov týkajúcich sa oprávnenosti, či neoprávnenosti zaradenia niektorých služieb do poštového sektora bol v rámci EÚ prijatý ako východisko pri definovaní poštového sektora model, podla ktorého je subjekt poskytujúci poštové služby súčast'ou poštového sektora. $\mathrm{K}$ definovaniu poštového sektora je teda nevyhnutné v prvom rade definovat' poštovú službu. Smernica 97/67/EC Európskeho parlamentu a Rady o spoločných pravidlách pre rozvoj vnútorného trhu poštových služieb Spoločenstva a zvyšovanie kvality služby definuje poštové služby ako „služby zahŕnajúce zber, triedenie, prepravu a dodanie poštových zásielok“, pričom poštová zásielka je „zásielka s adresou v konečnej podobe, v ktorej má byt' dodaná poskytovatel'om univerzálnej služby; mimo zásielok s aktuálnym oznámením sú to taktiež napríklad knihy, katalógy, noviny, periodická tlač a poštové balíky obsahujúce tovar s obchodnou hodnotou, či bez obchodnej hodnoty".

\section{Právne normy definujúce prostredie sektora poštových služieb EÚ}

- Smernica 97/67/EC Európskeho parlamentu a Rady o spoločných pravidlách pre rozvoj vnútorného trhu poštových služieb Spoločenstva a zvyšovanie kvality služby (jej základným ciel’om je vytvorenie jednotného európskeho trhu poštových služieb, nakol'ko tieto sú jedným zo základných nástrojov komunikácie a obchodu.),

- Vyhláška č. 98/EC 39/02 Európskej komisie o uplatňovaní pravidiel konkurencie na poštový sektor o hodnotení niektorých štátnych opatrení vzt’ahujúcich sa k poštovým službám (je zameraná na nevyhnutnost' stále vyššieho uplatňovania konkurenčných princípov v poštovom sektore, stanovuje, ako treba vnímat' dominantné postavenie verejného poštového operátora, spravidla držitel'a poštovej licencie jednotlivých

\footnotetext{
* Ing. Lucia Madleňáková, PhD., Katedra spojov, Fakulta prevádzky a ekonomiky dopravy a spojov, Žilinská univerzita v Žiline, univerzitná 1, 01026 Žilina, Slovenská republika, tel. č.: +421415133125 , fax: +421415655615 , email: Lucia.Madlenakova@fpedas.utc.sk
} 
členských štátov. Vel'mi podrobne sa tiež zaoberá princípmi a dôsledkami krížového financovania a verejnými podnikmi so zvláštnymi alebo výhradnými právami. Nie je povinnost'ou členských štátov túto vyhlášku plne rešpektovat', ale sama osebe však predstavuje vel'ký tlak na liberalizáciu poštových služieb formulovaných Smernicou 97/67/EC.),

- Smernica 2002/39/EC Európskeho parlamentu a rady pozmeňujúca Smernicu č. 97/67/EC, pokial' ide o d'alšie otváranie poštových služieb Spoločenstva konkurencii (nanovo stanovuje hmotnostné a cenové limity vyhradených služieb, a to tak, že doterajší hmotnostný limit 350g sa znižuje od 1.1.2003 na 100g a od 1.1.2006 na 50g, doterajší cenový limit - pät'- násobok verejnej tarify za zásielku prvého stupňa hmotnosti najrýchlejšej štandardnej kategórie na trojnásobok tejto tarify od 1.1.2003 a na dva a pol násobok tejto tarify od 1.1.2006.).

Všetky členské štáty EÚ sú povinné dodržiavat' ustanovenia jednotlivých smerníc. Aplikačným nástrojom sú spravidla predmetné národné právne normy. To isté sa týka aj krajín snažiacich sa o vstup do EÚ, ktoré tak musia v rámci prístupových rokovaní vykazovat' jej dodržiavanie.

\section{Vymedzenie poštového sektora SR}

Vymedzenie poštového sektora, t.j. stanovenie, ktoré služby a subjekty sú súčast'ou poštového sektora, je komplikovaná záležitost', ked’že aj verejný poštový operátor poskytuje bankové, peňažné či iné služby, ktorých zaradenie do poštového sektora je sporné, a taktiež ostatní poskytovatelia prepravných služieb majú vo svojej ponuke služby, ktoré by sa dali do tohto sektora zaradit'.

Národná legislatíva SR, konkrétne zákon č. 507/2001 Z.z. zo 6. novembra 2001 o poštových službách v znení zákona 15/2004 Z.z., definuje poštové služby ako ,činnosti, ktoré zahŕnajú vyberanie, triedenie, prepravu a dodávanie poštových zásielok." Tento zákon definuje poštové zásielky ako „oznámenia alebo veci adresované a upravené do takej konečnej podoby, $v$ akej ich má povinnost' dodávat' poskytovatel univerzálnej služby. Minimálne a maximálne rozmery poštových zásielok určujú pravidlá pre medzinárodný poštový styk."

\section{Špecifiká sektora poštových služieb}

Poštový sektor v rámci EÚ je špecifický najmä dvoma protichodne pôsobiacimi silami. Na jednej strane sú to požiadavky jednotného trhu, pokial' ide o vol'ný trh, vol'nú konkurenciu, ekonomickú výkonnost' a dynamiku, a na strane druhej sú ciele všeobecného záujmu. Zaistit' rovnováhu medzi týmito dvoma silami je vel'mi zložité, lebo vymedzený priestor je v neustálom pohybe: jednotný trh neustále expanduje a verejné služby nielenže nie sú nemenné, ale dokonca sa musia prispôsobovat' novým požiadavkám.

Ciele v oblasti všeobecného záujmu sú zrejmé zo správy Európskej komisie zo dňa 11.9.1996 o službách všeobecného záujmu v Európe. Základnými ciel'mi sú podl’a nej solidarita a rovnoprávne zachádzanie v rámci trhovej ekonomiky. Tieto ciele sú podporované práve službami všeobecného záujmu. Európania totiž očakávajú služby vysokej kvality za dostupné ceny a mnohí z nich dokonca považujú služby všeobecného záujmu za sociálne právo.

Výsledkom tohto snaženia je ustanovenie Smernice 97/67/EC: „Členské štáty zaistia, aby uživatelia mohli využivat' právo na univerzálnu poštovú službu zahŕñajúce trvalé poskytovanie poštovej služby v stanovenej kvalite vo všetkých prístupových bodoch na ich území za dostupné ceny pre všetkých obyvatel'ov."

Vzhl'adom k finančnej náročnosti univerzálne poskytovaných služieb bol poskytovatel'om univerzálnej služby vyhradený určitý rozsah služieb nevyhnutný pre realizáciu ciel'ov všeobecného záujmu a vd'aka tomuto zvýhodneniu sú schopní financovat' univerzálnu službu. 
Okrem toho je nevyhnutné zaistit', aby moc monopolu nebola zneužívaná na rozširovanie chráneného dominantného postavenia, alebo k neoprávnenej diskriminácii v prospech vel'kých zákazníkov, na úkor drobných užívatel’ov. V neposlednom rade je dôležité zabránit' vytváraniu alebo udržiavaniu nezákonných cenových kartelov poškodzujúcich záujmy spoločenstva a spotrebitel’ov v EÚ.

Vzhl'adom k permanentným tlakom ako zo strany národných súkromných poskytovatel'ov poštových služieb (tlak motivovaný snahou o dosiahnutie väčšieho zisku), tak i zo strany WTO, ktorá zásadne odmieta akýkol'vek monopol, je rozsah monopolu neustále posudzovaný s ciel'om ho redukovat'. Dôsledkom tohto snaženia bolo prijatie Smernice 2002/39/EC, ktorou sa nanovo definujú hmotnostné a cenové limity vyhradenej oblasti.

Liberalizácia predstavuje proces odstraňovania prekážok slobodného podnikania na poštovom trhu. Pričom slobodné podnikanie treba chápat' ako podnikanie pri dodržiavaní zákonov, morálnych a etických princípov a za transparentných a rovnakých podmienok pre všetkých záujemcov o podnikanie na uvedenom trhu.

\section{Vecná regulácia sektora poštových služieb SR}

Vecná regulácia sektora poštových služieb vychádza zo zákona o poštových službách, prostredníctvom ktorého definuje podmienky poskytovania univerzálnej služby, ale aj podmienky pre poskytovanie ostatných poštových služieb. Tieto podmienky do konkrétnej podoby uvádza Poštový regulačný úrad svojimi rozhodnutiami (všeobecné povolenie, poštová licencia).

Podmienky poskytovania poštových služieb je vel'mi t’ažké popísat' vo všeobecnosti, ked’že každá krajina má svoje špecifiká. Pri regulovaní týchto podmienok sa kladie dôraz najmä na kvalitu poskytovaných služieb.

Kvalita univerzálnej služby je zameraná predovšetkým na lehoty, pravidelnost' a spol'ahlivost' služieb. Kvalitu poskytovania univerzálnej poštovej služby možno posudzovat' tak z hl'adiska jej dostupnosti a to miestnej a časovej, ako aj z hl'adiska plnenia limitov včasnosti dopravy.

Požiadavky na miestnu a časovú dostupnost' univerzálnej služby sa v SR uvádzajú dvoma ukazovatel'mi:

- vzdialenost' medzi poštami a poštovými schránkami,

- počet obyvatel'ov pripadajúcich na jednu poštu, resp. na poštovú schránku.

Slovenská pošta, a.s., je v zmysle poštovej licencie povinná splnit' (do 1.1.2007) nasledovné rozvojové a kvalitatívne ukazovatele:

$>$ dosiahnut' plnenie včasnosti dopravy listov 1. triedy na $96 \%$ a listov 2 . triedy na $94 \%$,

$>$ dosiahnut' plnenie včasnosti dopravy balíkov 1. triedy a balíkov 2. triedy na 95,5\%,

$>$ zlepšovat' dostupnost' univerzálnej poštovej služby podl'a požiadaviek na kvalitu univerzálnej poštovej služby,

$>$ vytvárat' podmienky na minimalizovanie miest bez doručovacej služby a znižovat' počet týchto miest,

$>$ ročne zvyšovat' operatívnost' a kvalitu univerzálnej poštovej služby automatizáciou pôšt.

Jedným z najväčších aktuálnych problémov, ktorý spadá do oblasti vecnej regulácie poštových služieb, je liberalizácia poštových služieb, poskytovaných v rámci poštovej výhrady.

Všeobecný trend liberalizácie - znižovanie rozsahu poštovej výhrady je z pohl’adu Slovenskej pošty, a.s. nevýhodné. Tá pritom argumentuje tým, že pri urýchlení liberalizačného procesu by z dôvodu zníženia objemu výnosov bolo ohrozené poskytovanie univerzálnej poštovej služby. Poštový regulačný úrad má naopak snahu urýchlit liberalizáciu, čo by viedlo k urýchleniu fungovania trhových mechanizmov, a následne k zvýšeniu kvality poskytovaných služieb. 
Nasledujúci obrázok popisuje percentuálny podiel jednotlivých hmotnostných kategórií podaných listov 2. triedy od roku 1997.

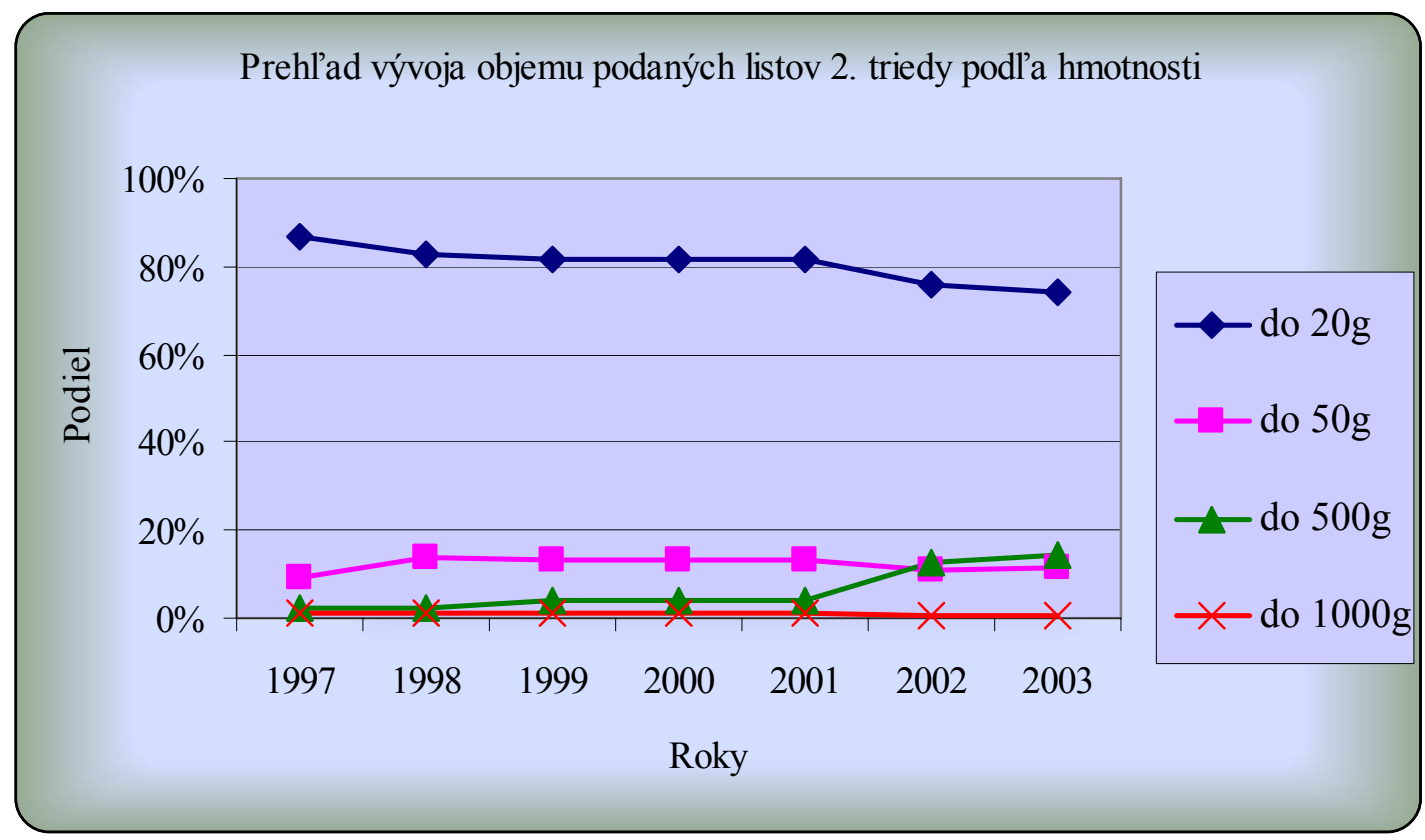

Obr 1 Prehl'ad vývoja objemu podaných listov 2. triedy podl'a hmotnosti

Vývoj je dost' vyrovnaný a dôležité je poukázat' na zmeny v podieloch hmotnostných kategórií v posledných rokoch na celkovom objeme podaných listov 2 . triedy, nakol'ko práve v tomto období sa znižoval rozsah poštovej výhrady. Na prelome rokov 2002 a 2003 sa objem listov 2. triedy do $1000 \mathrm{~g}$ znížil, ale len minimálne. V kategórii do $500 \mathrm{~g}$ sa podiel zvýšil, aj napriek tomu, že už nepatrila do poštovej výhrady a konkurencia mohla poskytovat' túto službu bez podmienky zvýšenia ceny minimálne na úroveň 3 - násobku podl'a tarify poskytovatel'a univerzálnej poštovej služby. Podiel hmotnostnej kategórie do $50 \mathrm{~g}$ mal stály vývoj a výrazne sa nemenil. Najväčší podiel na celkovom objeme podaných listov 2. triedy má hmotnostná kategória do $20 \mathrm{~g}$. Ten sa po znížení výhrady na $350 \mathrm{~g}$ znížil, aj napriek tomu, že 20 gramová kategória zostala nad’alej vyhradená Slovenskej pošte, a.s..

Aj z uvedeného prehl'adu vyplýva, že znižovanie poštovej výhrady neznižuje podiel poštových služieb poskytovaných Slovenskou poštou, a.s., ktoré už do výhrady nepatria. To uprednostňuje snahu Poštového regulačného úradu o urýchlenie liberalizácie na poštovom trhu v SR. V súčasnosti je obsahom poštovej výhrady vyberanie a distribúcia:

a) korešpondencie a reklamných adresovaných zásielok s hmotnost'ou najviac $50 \mathrm{~g}$,

b) korešpondencie určenej do vlastných rúk účastníkom súdnych konaní a konaní pred správnymi orgánmi. zásielky, ak

Poštová výhrada sa však nevzt’ahuje na korešpondenciu a reklamné adresované

$>$ poštová sadzba za ňu je rovnaká alebo vyššia ako jej dvaapolnásobok podl’a tarify poskytovatel'a univerzálnej služby pre korešpondenciu v prvom hmotnostnom stupni najrýchlejšej štandardnej kategórie,

$>$ je sprievodným dokladom vecí, ktoré sa súčasne dodávajú alebo ak ju vo vnútroštátnom styku distribuuje poštový podnik, ktorý ju vybral v cudzine. 


\begin{tabular}{|c|c|c|}
\hline $\begin{array}{c}\text { Termín zníženia rozsahu } \\
\text { poštovej výhrady }\end{array}$ & Hmotnostný limit & Cenový limit \\
\hline Do 31.12.2003 & $1000 \mathrm{~g}$ & 5-násobok \\
\hline Od 1.1.2004 do 30.4.2004 & $350 \mathrm{~g}$ & 3-násobok \\
\hline Od 1.5.2005 do 31.12.2005 & $100 \mathrm{~g}$ & 3-násobok \\
\hline Od 1.1.2006 & $50 \mathrm{~g}$ & 2,5-násobok \\
\hline
\end{tabular}

Obr 2 Prehl'ad postupného znižovania rozsahu poštovej výhrady

Termín úplného zrušenia poštovej výhrady a realizácia plnej liberalizácie poštových služieb zatial' legislatívne vymedzený nie je. EÚ však predpokladá koniec roka 2009.

\section{Cenová regulácia sektora poštových služieb}

Oblast' cenovej regulácie je legislatívne upravená Smernicou 97/67/EC, kde piata kapitola - Tarifné princípy a priehl'adnost' účtov zaväzuje členské štáty, aby urobili potrebné kroky zabezpečujúce, že tarify pre každú zo služieb tvoriacich súčast' univerzálnej služby budú v súlade s nasledujúcimi princípmi:

- ceny musia byt' dostupné a musia byt' také, aby všetci užívatelia mali prístup k poskytovaným službám,

- ceny musia byt' stanovené vo vzt'ahu k nákladom; členské štáty môžu rozhodnút, že na celom ich území bude aplikovaná jedna tarifa,

- aplikácia jednotnej tarify vylučuje právo poskytovatel'a / poskytovatel'ov univerzálnej služby uzatvárat' so zákazníkmi individuálne dohody o cenách,

- tarify musia byt' prehl'adné a nediskriminačné.

Ustanovenia predmetnej smernice upravujú aj princípy účtovníctva verejného poštového operátora, a to tak, že ,verejní poštoví operátori budú viest' vo svojich účtoch interných účtovných systémoch oddelené účty minimálne pre každú zo služieb vyhradeného sektora na jednej strane a pre nevyhradené služby na strane druhej. Účty za nevyhradené služby by sa mali zretel'ne odlišovat' od služieb, ktoré sú súčast'ou univerzálnej služby a službami, ktoré nie sú.

Toto ustanovenie má zabránit’ tomu, aby verejný poštový operátor neporušoval zásady vol'nej konkurencie tým, že by náklady na prevádzku siete prirad'oval len k jemu vyhradeným službám, pričom ostatné služby ním poskytované by logicky prevádzkoval za nižšie náklady ako ostatní poskytovatelia. Inak povedané, je nevyhnutné dohliadat' na to, aby verejný poštový operátor pridel'oval náklady zásadne tým službám, ktorých sa týkajú.

Cenovú reguláciu je možné realizovat' prostredníctvom rôznych modelov:

$>$ schválenie poštových sadzieb príslušným orgánom štátnej správy (v SR Poštový regulačný úrad),

$>$ regulácia stupňa výnosnosti, ktorý sa snaží zaistit’ taký prístup, aby boli ceny stanovené na úrovni, ktorá umožní držitel'ovi poštovej licencie pokryt' všetky jeho náklady na tie produkty a služby, pre ktoré sú jednotlivé ceny stanovené, pričom je do nich zaúčtovaný aj primerane adekvátny zisk; ide o tzv. „cost-plus“, ktorý dovol'uje, aby boli všetky nevyhnutné náklady vrátane zisku pokryté užívatel'om služby; nedostatok tohto modelu spočíva v tom, že nepodnecuje ku znižovaniu nákladov,

$>$ princíp cenového stropu - „price-cap“ je najčastejšie používaný v rozvinutých ekonomikách, je považovaný za najvhodnejší pre sektor poštových služieb, a to predovšetkým z hl'adiska motivácie regulovaného subjektu.

\section{Cenová regulácia sektora poštových služieb SR}

Cenová regulácia je všeobecne definovaná Zákonom č. 18/1996 Z. z. o cenách v znení neskorších predpisov. Tento zákon reguláciu cien uvádza ako „určenie ceny alebo 
usmerňovanie dohodovania cien cenovými orgánmi, ktorými sú ministerstvo, okresné úrady alebo iný orgán štátnej správy“. Rozhodnutia týchto cenových orgánov o regulácii cien sú záväzné.

Primárnym ciel'om cenovej regulácie v sektore poštových služieb je vylúčenie možnosti zneužívania právomocí držitela poštovej licencie prostredníctvom príliš vysokých cien monopolne poskytovaných služieb. Ďalej je to podpora konkurencie, tlak na vyhl'adávanie neustálych zlepšení efektivity, ktorá musí viest' k znižovaniu reálnych cien, aj podpora neustáleho zlepšovania kvality poskytovaných služieb. predpisov:

Poštový regulačný úrad vykonáva reguláciu cien úradným určením podl’a osobitných

$>$ určenie maximálnych alebo pevných cien a určenie taríf a tarifných podmienok,

$>$ určenie záväzných podmienok výroby, dodávok a nákupu,

$>$ určenie ekonomicky oprávnených nákladov a primeraného zisku vrátane rozsahu investícií, ktoré možno do cien a taríf započítat'.

Regulácii podliehajú poštové sadzby za poskytovanie univerzálnej poštovej služby $\mathrm{v}$ rozsahu uvedenom $\mathrm{v}$ poštovej licencii a za vykonávanie poštového platobného styku. Sadzby za službu univerzálnu tuzemského styku sú určené ako maximálne ceny, ktoré nie je možné prekročit'. Vecné usmerňovanie cien bolo v roku 2004 zrušené. Na medzinárodné sadzby univerzálnej poštovej služby sa zákon o cenách nevzt’ahuje. Regulácia sa vykonáva $\mathrm{v}$ zmysle Aktov Svetovej poštovej únie.

Sadzby za poskytovanie ostatných poštových služieb mimo univerzálnej služby, ktoré nepodliehajú štátnej regulácii, sa stanovujú dohodou podl'a zákona o cenách. Tieto sadzby určuje Slovenská pošta, a.s., a na rozdiel od univerzálnej služby, podliehajú zdaneniu daňou z pridanej hodnoty. Platné poštové sadzby (regulované i neregulované) obsahuje Tarifa SP, a.s., ktorá je dostupná na každej pošte.

\section{Záver}

Pri riešení otázky vecnej a cenovej regulácie je potrebné analyzovat' predovšetkým príčiny existencie nedokonalej konkurencie $\mathrm{v}$ sektore poštových služieb a potrebu ju regulovat'. Vo všeobecnosti možno povedat', že nedokonalá konkurencia na trhu vzniká pri existencii malého počtu operátorov. Jej dvoma základnými zložkami sú nákladové podmienky a prekážky konkurencie. Kde najmä verejný operátor ako držitel' poštovej licencie má pridelené zvláštne právo poskytovat' isté služby v rámci poštovej výhrady. Vzniká tu nutnost' regulácie poštového sektora $\mathrm{v}$ snahe dostat’ danú situáciu pod kontrolu.

\section{Literatúra}

[1] ČOREJOVÁ, T., GOČALOVÁ, L.: Faktory ovplyvňujúce hodnotový ret’azec v poštových službách. In: Medzinárodná konferencia zástupcov poštových správ a univerzít. Katedra spojov - ŽU Žilina : Žilina 28. - 30. september 2005 : zborník prednášok. - Žilina: Žilinská univerzita, 2005. - ISBN 80-8070-454-6. - S. 72-76.

[2] HODÁKOVÁ, M.: Liberalization and postal regulation in the Central and Eastern European countries. In: Studies of Faculty of Operation and Economics of Transport and Communications of University of Žilina - S. 77-83, 2004

[3] MADLEŇÁK, R, MADLEŇÁKOVÁ, L.: The postal market analysis in Europe. In: Studies of Faculty of operation and economics of transport and communications of University of Žilina : Volume 19. - Žilina: University of Žilina, 2003. - ISBN 80-8070096-6. - S. 117-122.

[4] MADLEŃÁKOVÁ, L.: Výskum metód pre hodnotenie kvality z pohl'adu regulátora so zameraním na poštu. Dizertačná práca doktorandského štúdia, Katedra spojov Fakulty prevádzky a ekonomiky dopravy a spojov Žilinskej univerzity v Žiline; Žilina 2003. 
[5] ŠVADLENKA, L., HODÁKOVÁ, M.: Kvalitnější nabídka služeb. Logistika, 2005, č. 3, s. 40 - 41. ISSN 1211-0957

[6] Smernica 97/67/EC Európskeho parlamentu a rady o spoločných pravidlách rozvoja vnútorného trhu poštových služieb Spoločenstva a zlepšovaní kvality služieb

[7] Smernica Európskeho parlamentu a Rady 2002/39/EC, ktorou sa mení a dopín̆a smernica 97/67/EC z hl'adiska d’alšej liberalizácie trhu poštových služieb spoločenstva

[8] Zákon č. $18 / 1996$ Z. z. o cenách v znení neskorších predpisov.

[9] Zákon č. 507/2001 Z. z. o poštových službách v znení zákona č. 15/2004 Z. z.

[10] http://www.telecom.gov.sk/index/go.php?id=1468 